\title{
SINTESIS DAN PENINGKATAN PERFORMA BAHAN BAKAR BRIKET DARI LIMBAH ABU DASAR BATUBARA DAN LIMBAH SABUT KELAPA DI INDUSTRI TEKSTIL
}

\author{
SYNTHESIS AND PERFORMANCE IMPROVEMENT OF BRIQUETTE FUEL \\ FROM COAL BOTTOM ASH AND COCONUT COIR WASTES \\ IN TEXTILE INDUSTRY
}

\author{
Achmad Sjaifudin T., Doni Sugiyana \\ Balai Besar Tekstil, Jalan Jenderal Ahmad Yani No. 390 Bandung \\ E-mail: texirdti@bdg.centrin.net.id
}

Tanggal diterima: 22 Juli 2016, direvisi: 2 November 2016, disetujui terbit: 3 November 2016

\begin{abstract}
ABSTRAK
Pada penelitian ini dipelajari sintesis bahan bakar briket dengan memanfaatkan bahan baku limbah abu dasar batubara dan limbah sabut kelapa dari industri tekstil dan peningkatan performanya. Penelitian dilakukan melalui optimasi dari beban kompaksi dan komposisi abu dasar batubara, sabut kelapa dan bahan pengikat molase pada proses pembriketan sehingga dapat memenuhi persyaratan standar briket. Proses pengarangan pada interval temperatur $150-300^{\circ} \mathrm{C}$ dan impregnasi $\mathrm{NaCl}$ pada variasi konsentrasi $0,01-0,05 \%$ dipelajari untuk mengetahui pengaruhnya terhadap nilai kalori bahan baku. Evaluasi performa briket dilakukan terhadap capaian kuat tekan dan nilai kalori briket yang diperoleh. Proses pengarangan pada temperatur $300^{\circ} \mathrm{C}$ mampu meningkatkan nilai kalori sabut kelapa dari $4240 \mathrm{kkal} / \mathrm{kg}$ menjadi $7122 \mathrm{kkal} / \mathrm{kg}$. Impregnasi pada konsentrasi $\mathrm{NaCl} 0,02 \%$ selama 24 jam hanya dapat meningkatkan nilai kalori dari $2.177 \mathrm{kkal} / \mathrm{kg}$ menjadi $2.764 \mathrm{kkal} / \mathrm{kg}$. Beban kompaksi optimum pada $500 \mathrm{kgf}$ memberikan nilai kuat tekan briket sebesar 135,99 kgf/ $\mathrm{cm}^{2}$. Evaluasi terhadap briket yang dihasilkan menunjukkan bahwa performa briket optimum diperoleh pada perbandingan komposisi abu dasar : sabut kelapa : molase sebesar 42,5 : 42,5 : 15 dengan nilai kalori sebesar $4.524 \mathrm{kkal} / \mathrm{kg}$ dan kuat tekan $69,58 \mathrm{kgf} / \mathrm{cm}^{2}$.
\end{abstract}

Kata kunci: abu dasar, briket, kuat tekan, nilai kalori, sabut kelapa

\section{ABSTRACT}

Synthesis of briquette fuel by utilizing bottom ash and coconut coir wastes from textile industry as raw material and improvement of its performance were studied in this research. Research was carried out through optimization of compaction load and compositon of bottom ash, coconut coir and molasses as binder in briquetting process, in order to meet the standard requirement of briquette. Carbonization of coconut coir in temperature interval of $150-300^{\circ} \mathrm{C}$ and impregnation of bottom ash in various concentration of 0,01\%-0,05\% were also studied to find out its effect to calorific value of raw materials. Evaluation of briquette performance was carried out through measurement of pressure strength and calorific value of the obtained briquette. Carbonization at $300^{\circ} \mathrm{C}$ was effectively increased calorific value of coconut coir from $4240 \mathrm{kcal} / \mathrm{kg}$ into $7122 \mathrm{kcal} / \mathrm{kg}$. Impregnation using $\mathrm{NaCl}$ $0.02 \%$ by 24 hrs were only increased calorific value ofbottom ash from 2,177 kcal/kginto 2,764 kcal/kg. Optimized compaction load at $500 \mathrm{kgf}$ resulted in briquette pressure strength of $102.72 \mathrm{kgf} / \mathrm{cm}^{2}$. Evalution to the obtained briquette shows that optimized briquette performance were obtained from composition of bottom ash : coconut coir : molasse $=42.5: 42.5: 15$ with calorific value of $4,524 \mathrm{kcal} / \mathrm{kg}$ and pressure strength of $69.58 \mathrm{kgf} / \mathrm{cm}^{2}$.

Keywords: bottom ash, briquette, pressure strength, coconut coir, calorific value

\section{PENDAHULUAN}

Penggunaan batubara sebagai bahan bakar di industri tekstil menghasilkan limbah padat berupa abu terbang (fly ash) dan abu dasar (bottom ash) dengan jumlah kurang lebih 1 juta ton per tahun. ${ }^{1}$ Dari total limbah abu ini, $70-80 \%$ adalah limbah abu terbang, sedangkan sisanya adalah abu dasar yang masih mengandung karbon yang cukup tinggi. Nilai kalori dari limbah abu dasar dapat mencapai $3225 \mathrm{kkal} / \mathrm{kg}$, sehingga berpotensi untuk dimanfaatkan sebagai bahan bakar., ${ }^{2,3}$ Namun demikian limbah abu dasar memiliki senyawa zat terbang (volatile matter) yang rendah sehingga menyebabkan abu dasar relatif sulit terbakar. Pencampuran dengan material lain yang kaya akan zat terbang akan membantu proses pembakarannya. Sabut kelapa merupakan limbah dari industri geotekstil yang menggunakan serat alam (kelapa 
dan jute), dengan produksi limbah sabut kelapa mencapai 0,5 ton/hari. Limbah sabut kelapa mempunyai kadar zat terbang yang tinggi mencapai $60-70 \%$ dan nilai kalori yang cukup tinggi yaitu berkisar 3900-4000 $\mathrm{kkal} / \mathrm{kg}, \quad$ sehingga memungkinkan untuk digunakan sebagai campuran bahan bakar. ${ }^{4}$

Permasalahan lain pada limbah abu dasar adalah ukuran butir yang halus, sehingga sulit untuk dimanfaatkan secara langsung sebagai bahan bakar. Sebagai solusinya diperlukan pemadatan dengan cara pembriketan. Briket merupakan bahan bakar padat yang telah mengalami proses kompaksi dengan bentuk dan ukuran tertentu, yang tersusun dari butiran halus dari bahan yang mengandung karbon tinggi dengan sedikit pencampuran pengikat, agar bahan bakar tersebut lebih mudah ditangani. ${ }^{\mathbf{5 , 6}}$ Proses pembriketan pada abu dasar batubarajuga bertujuan agar pemanfaatannya sebagai bahan bakar daur ulang menjadi lebih mudah. Bahan pengikat dalam pembuatan briket antara lain kanji, tanah liat, molase, resin fenol, dan sebagainya. ${ }^{6,7}$ Molase adalah salah satu bahan pengikat organik yang memiliki daya rekat yang baik dan mampu meningkatkan nilai kalori campuran briket. Molase merupakan produk samping dari gula tebu dan sudah diproduksi secara massal.

Penelitian pemanfaatan abu dasar telah dilakukan baik sebagai sumber energi maupun diproses menjadi karbon aktif sebagai adsorben untuk pengolahan air limbah. ${ }^{\mathbf{4}}$ Penelitian sebelumnya mengenai pembriketandengan komposisi abu dasar dan limbah sabut kelapa dengan bahan pengikat kanji belum mencapai nilai kalori dan kuat tekan yang memenuhi persyaratan. ${ }^{4}$ Produk briket abu dasar batu bara dan sabut kelapa harus memenuhi syarat teknis SNI 19-4791-1998 yaitu nilai kalori antara 4500-5000 kkal/kg dan kekuatan tekan minimum $60 \mathrm{kgf} / \mathrm{cm}^{2}$. Penelitian lainnya antara lain dengan menggunakan metode pengayaan karbon dengan teknik secara biologi dan mekanis (pembriketan) dan berhasil mencapai nilai kalori yang memenuhi syarat, namun proses ini memerlukan waktu yang panjang, biaya yang tinggi dan pemeliharaan/perawatan yang relatif sulit. ${ }^{9}$

Dalam penelitian ini dipelajari pembuatan bahan bakar briket dari limbah abu dasar batu bara dan limbah sabut kelapa, dengan bahan pengikat molase. Penelitian ini bertujuan untuk menyempurnakan metode pada penelitian sebelumnya, ${ }^{4}$ sehingga diperoleh briket yang memenuhi persyaratan teknis nilai kalori dan kuat tekan untuk digunakan sebagai sebagai bahan bakar padat. Dampak jangka panjang dari studi ini diharapkan dapat meningkatkan potensi pemanfaatan limbah padat industri tekstil menjadi suatu produk yang bernilai ekonomi sekaligus mengurangi masalah lingkungan.

\section{METODE}

\section{Bahan dan Peralatan Penelitian}

Limbah abu dasar yang digunakan pada penelitian ini berasal dari 2 (dua) industri tekstil yang menggunakan batubara sebagai bahan bakar boiler dengan tipe boiler fluidized bed. Limbah sabut kelapa diambil dari satu industri pembuatan geotekstil dari serat alam kelapa yang dihasilkan dalam proses pengambilan serat dari sabut kelapa menggunakan mesin pengurai sabut kelapa.

Bahan pengikat molase diencerkan dengan metanol teknis dengan perbandingan beratmolase : metanol $=80: 20$. Hasil pengujian terhadap larutan molase akhir menunjukkan nilai viskositas dan massa jenis masing-masing sebesar 1837,5 centipoises dan 1,29 gram $/ \mathrm{cm}^{3}$. $\mathrm{NaCl}$ (Merck) dengan konsentrasi $0,1 \%$ dilarutkan dalam aquadest untuk digunakan dalam percobaan impregnasi.

Peralatan yang digunakan dalam penelitian ini antara lain :

- Alat press dengan kapasitas maksimum 700 $\mathrm{kgf} / \mathrm{cm}^{2}$.

- Cetakan briket terbuat dari bahan baja yang terdiri dari 3 komponen seperti terlihat pada Gambar 1 dengan diameter briket $1,5 \mathrm{~cm}$. Ketebalan sampel diatur sesuai banyaknya sampel dan tekanan yang digunakan.

- Tungku listrik skala laboratorium.

- Oven pengering (gas LPG).

- Disc mill.

- Mesin pengaduk skala laboratorium.

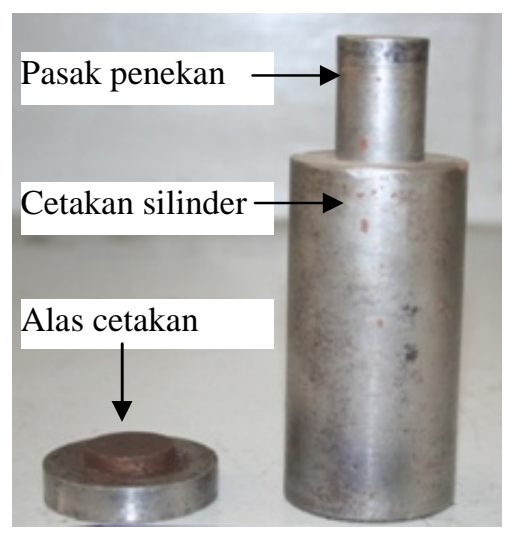

Gambar 1. Cetakan briket

\section{Preparasi bahan baku}

Pada tahap preparasi, bahan baku berupa limbah abu dasar batubara dicuci dan dikeringkan, untuk selanjutnya dihaluskan hingga ukuran 20 mesh. Abu dasar diaduk untuk mendapatkan campuran yang homogen. Analisis nilai kalori dan proksimat dilakukan terhadap campuran abu dasar yang telah homogen.

Sabut kelapa dibersihkan dari debu pengotor (coco peat dan coco dust) hingga kemudian 
diperoleh bagian serat kasar sabut kelapa.Sabut kelapa dihaluskan hingga ukuran 20 mesh untuk kemudian dianalisis nilai kalori dan proksimatnya. Pengukuran densitas dan viskositas dilakukan terhadap bahan baku molase untuk menentukan nilai yang memberikan daya ikat terbaik.

\section{Percobaan pengarangan dan impregnasi}

Percobaan pengarangan dilakukan pada bahan baku sabut kelapa untuk mengetahui pengaruh pengarangan terhadap peningkatan nilai kalori. Temperatur pengarangan dilakukan pada variasi nilai : $100-150-200-250-300^{\circ} \mathrm{C}$. Percobaan impregnasi (perendaman) di dalam larutan $\mathrm{NaCl}$ dilakukan pada bahan baku abu dasar batubara untuk mengetahui konsentrasi $\mathrm{NaCl}$ optimum sehingga diperoleh peningkatan nilai kalori abu dasar. Variasi konsentrasi larutan $\mathrm{NaCl}$ yang digunakan adalah : 0,01- 0,02 - 0,03- 0,04 $0,05 \%$ (volume/volume).

\section{Variasi komposisi bahan pengikat}

Bahan baku dalam variasi percobaan ini adalah : abu dasar yang tidak diimpregnasi, arang sabut kelapa (sabut kelapa yang dipanaskan pada $300^{\circ} \mathrm{C}$ ) dan molase. Bahan baku dicampur dengan variasi komposisi molase : 5 - 10 - 15 - 20 - 25 $30 \%$ (persentase berat), sedangkan komposisi jumlah abu dasar dan sabut kelapa dibuat tetap. Seluruh variasi campuran dibriket dengan dengan beban $500 \mathrm{kgf} / \mathrm{cm}^{2}$.

\section{Variasi Beban Kompaksi}

Pada variasi percobaan ini bahan baku yang digunakan adalah : abu dasaryang tidak diimpregnasi, arang sabut kelapa dan molase. Briket dibuat dengan komposisi persentase berat abu dasar : sabut kelapa : molase $=42,5: 42,5: 15$. Variasi beban kompaksi yang digunakan adalah: 400 - 450 - $500-550-600 \mathrm{kgf} / \mathrm{cm}^{2}$.

\section{Variasi Komposisi}

Pada percobaan variasi komposisi arang sabut kelapa digunakan komposisi arang (persentase berat) dengan variasi : $0-25-50-75$ - 100\%, dengan basis percobaan dengan 100 gram bahan baku briket dengan kadar abu dasar dan molase tetap yaitu masing-masing $75 \%$ dan $25 \%$ dari berat total campuran abu dasar dan molase. Pada variasi komposisi abu dasar (AD) yang tidak diimpregnasi dan arang sabut kelapa (SK) digunakan 5 variasi komposisi dengan kadar molase (M) tetap yaitu $15 \%$. Variasi komposisi AD:SK:M dengan persentase berat adalah: (a) 42,5:42,5:15; (b) $37,5: 47,5: 15$; (c) $32,5: 52,5: 15$; (d) 27,5:57,5:15 dan (e) 22,5:62,5:15. Basis percobaan adalah 100 gram campuran bahan baku briket dengan beban kompaksi pembriketan sebesar $500 \mathrm{kgf} / \mathrm{cm}^{2}$.

\section{Pengujian briket}

Metode penentuan komposisi proksimat, penentuan nilai kalori dan pengukuran nilai kuat tekan. Penentuan komposisi proksimat terdiri dari pengujian kadar/persentase air lembab (moisture), abu (ash), zat terbang (volatile matter) dan karbon. Pengujian proksimat dilakukan dengan menggunakan standar ASTM D-1762-84. Penentuan nilai kalor dilakukan mengikuti standar ASTM D-5865-01. Pengukuran nilai kuat tekan dilakukan dengan menggunakan force gauge Autograph Shimadzu.

\section{HASIL DAN PEMBAHASAN \\ Karakteristik bahan baku briket}

Hasil pengujian terhadap bahan bakubriket dapat dilihat pada Tabel 1. Bahan baku batubara yang digunakan memiliki nilai kalori yang tidak begitu tinggi. Hasil pengujian proksimat bahan baku setelah proses pembakaran menunjukkan hasil abu yang relatif besar. Pencucian abu dasar batubara menghasilkan penurunan jumlah abu (ash) sebesar $\pm 15 \%$. Penurunan kadar abu tidak terlalu signifikan karena proses pencucian dilakukan secara manual dengan tujuan hanya untuk memisahkan batubara yang tidak terbakar selama pembakaran.

Tabel 1. Proksimat bahan baku briket (basis udara kering /air dried basic)

\begin{tabular}{lcccc}
\hline \multirow{2}{*}{ Sampel } & \multicolumn{4}{c}{ Proksimat (persentase berat) } \\
\cline { 2 - 5 } & $\begin{array}{c}\text { Air } \\
\text { lembab }\end{array}$ & Abu & $\begin{array}{c}\text { Zat } \\
\text { terbang }\end{array}$ & Karbon \\
\hline Batu-bara & 26,64 & 1,72 & 37,25 & 34,39 \\
Abu dasar* & 3,79 & 76,8 & 2,90 & 16,49 \\
Abu dasar** & 5,77 & 59,9 & 2,85 & 31,41 \\
Sabut kelapa & 11,28 & 2,06 & 66,17 & 20,49 \\
\hline
\end{tabular}

*sebelum dicuci; **setelah dicuci

Tabel 2. Nilai kalori bahan baku (basis udara kering/ air dried basic)

\begin{tabular}{lc}
\hline Sampel & $\begin{array}{c}\text { Nilai kalori } \\
\text { (kkal/kg) }\end{array}$ \\
\hline Batubara bahan bakar & 4.594 \\
Abu dasar (sebelum dicuci) & 1.128 \\
Abu dasar (setelah dicuci) & 2.177 \\
Sabut kelapa & 4.240 \\
\hline
\end{tabular}

Pengaruh Pengarangan dan Impregnasi terhadap Nilai Kalori Bahan Baku Briket

Peningkatan nilai kalori bahan baku abu dasar dan sabut kelapa sangat menentukan nilai kalori akhir briket yang dihasilkan. Dalam penelitian ini peningkatan nilai kalori dilakukan dengan melakukan pengarangan terhadap sabut 
kelapa dan impregnasi terhadap abu dasar. Pengaruh pengarangan terhadap sabut kelapa dapat dilihat pada Gambar 2, sedangkan pengaruh impregnasi terhadap abu dasar dapat dilihat pada Gambar 3.

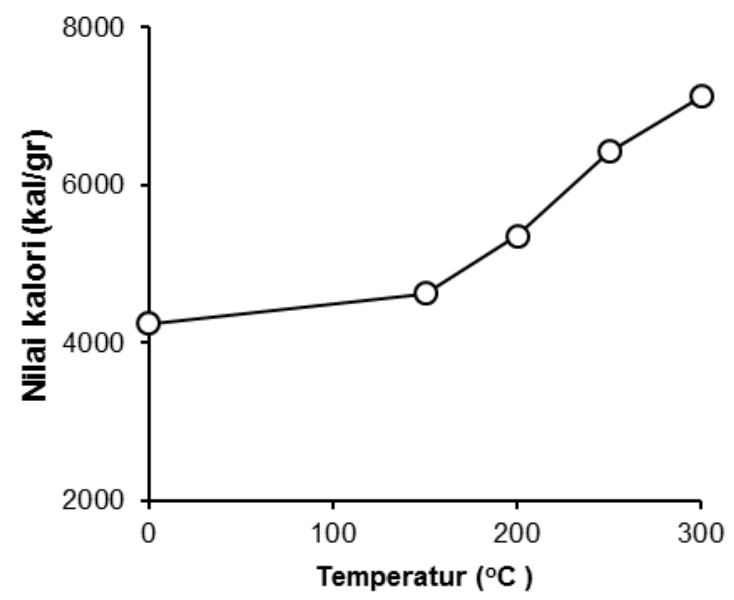

Gambar 2. Pengaruh temperatur pengarangan terhadap kenaikan nilai kalori sabut kelapa

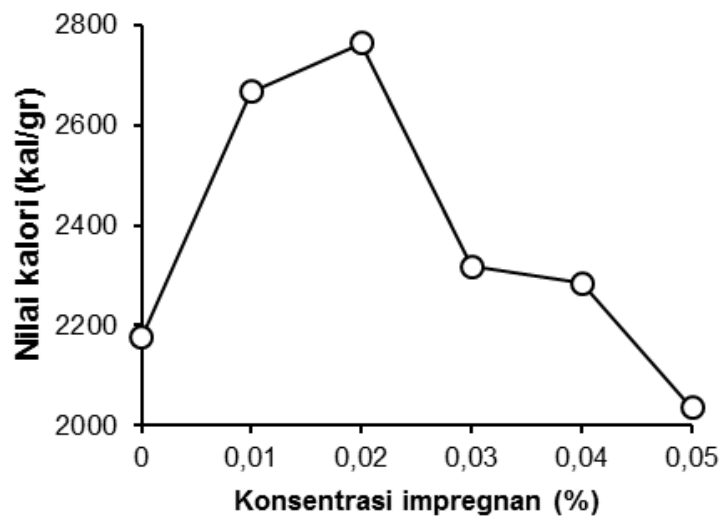

Gambar 3. Pengaruh konsentrasi impregnasi terhadap kenaikan nilai kalori abu dasar.

Pengarangan terhadap sabut kelapa mampu meningkatkan nilai kalori bahan seiring peningkatan temperatur proses. Melalui pengarangan pada temperatur $300^{\circ} \mathrm{C}$, nilai kalori sabut kelapa meningkat dari $4240 \mathrm{kkal} / \mathrm{kg}$ hingga $7122 \mathrm{kkal} / \mathrm{kg}$. Pada prinsipnya semakin tinggi temperatur pengarangan maka semakin tinggi nilai kalori bahan baku sabut kelapa. ${ }^{\mathbf{1 0}}$ Peningkatan nilai kalori ini disebabkan oleh pelepasan senyawa volatile sehingga meninggalkan residu berupa arang. ${ }^{11,12}$ Pada proses pengarangan biomassa, bahan organik yang terkandung dalam biomassa seperti selulosa, hemiselulosa dan lignin akan terdeformasi selama proses pengarangan. Selulosa $\left(\mathrm{C}_{6} \mathrm{H}_{10} \mathrm{O}_{5}\right)_{\mathrm{n}}$ akan terdeformasi pada interval suhu $325-375^{\circ} \mathrm{C}$, hemiselulosa $\left(\mathrm{C}_{5} \mathrm{H}_{8} \mathrm{O}_{4}\right)_{\mathrm{n}}$ akan terurai pada rentang temperatur $225-325^{\circ} \mathrm{C}$, sedangkan lignin $\left[\left(\mathrm{C}_{9} \mathrm{H}_{10} \mathrm{O}_{3}\right)\left(\mathrm{CH}_{3} \mathrm{O}\right)\right]_{\mathrm{n}}$ akan terdeformasi pada rentang temperatur $300-500^{\circ} \mathrm{C} .^{\mathbf{1 3 , 1 4}}$ Temperatur pengarangan sabut kelapa yang terlalu tinggi tidak direkomendasikan karena dapat menghilangkan senyawa lignin. Lignin merupakan bentuk senyawa karbon yang dapat berfungsi sebagai bahan pengikat alami pada proses pembriketan. ${ }^{15}$ Proses pengarangan dalam penelitian ini dilakukan pada temperatur maksimum $300^{\circ} \mathrm{C}$ dengan tujuan mempertahankan senyawa lignin.

Proses impregnasi selama 24 jam terhadap abu dasar memberikan peningkatan nilai kalori yang tidak terlalu signifikan. Peningkatan nilai kalori tertinggi diperoleh melalui impregnasi pada konsentrasi $\mathrm{NaCl} 0,02 \%$ dengan peningkatan nilai kalori dari $2.177 \mathrm{kkal} / \mathrm{kg}$ menjadi 2.764 kkal/kg.Nilai kalori abu dasar kembali menurun seiring peningkatan konsentrasi impregnan. Impregnasi merupakan proses pelarutan pengotor dan hidrokarbon di permukaan arang (karbon). Proses ini biasa digunakan pada pencucian karbon aktif yang telah lewat jenuh atau sebagai aktivator pada pembuatan karbon aktif. Konsentrasi larutan impregnan dan lamanya waktu impregnasi merupakan parameter yang perlu diperhatikan. Peningkatan konsentrasi larutan dan seiring proses impregnasi dapat meningkatkan nilai kalori pada nilai optimum. Pada konsentrasi impregnan lebih tinggi atau waktu impregnasi lebih lama, nilai kalori akan mengalami penurunan akibat terisinya pori-pori arang oleh partikel larutan impregnan. ${ }^{\mathbf{1 6}}$

\section{Evaluasi terhadap Kuat Tekan Briket}

Karakteristik awal yang dievaluasi dalam penelitian pembuatan briket ini adalah kekuatan mekaniknya. Kekuatan mekanik berupa kuat tekan sangat penting agar selama proses packaging dan transportasi, briket tidak hancur dan siap untuk digunakan.

Beberapa faktor yang mempengaruhi kuat tekan briket yaitu: humiditas material, beban kompaksi (variasi penekanan), temperatur penekanan, fraksi ukuran butir dan tipe material. $^{17,18}$ Tekanan kompaksi atau beban kompaksi yang diberikan dalam pembuatan briket akan menentukan kekuatan mekanik briket. Semakin besar tekan kompaksi maka briket akan semakin kuat. ${ }^{19}$ Pengaruh beban kompaksi terhadap kuat tekan briket dapat dilihat pada Gambar 4 .

Dalam penelitian ini (Gambar 4) beban kompaksi awal sebesar $400 \mathrm{kgf}$ memberikan kuat tekan $98 \mathrm{kgf} / \mathrm{cm}^{2}$. Peningkatan beban kompaksi hingga $400 \mathrm{kgf}$ mampu meningkatkan kuat tekan briket hingga $135,99 \mathrm{kgf} / \mathrm{cm}^{2}$. Namun peningkatan gaya penekanan melebihi $500 \mathrm{kgf}(550-600 \mathrm{kgf})$ ternyata berpengaruh pada penurunan kekuatan briket. Beban kompaksi 500 kgf terindikasi merupakan beban kompaksi optimum yang 
selanjutnya digunakan dalam percobaan selanjutnya pada penelitian ini. Penelitian sebelumnya oleh Davies, 2013 menunjukkan bahwa nilai kuat tekan (compressive strength) meningkat seiring naiknya nilai tekanan kompaksi (compaction pressure). ${ }^{19}$ Penyebab utama dari perbedaan ini adalah ketika gaya tekan yang diberi semakin besar maka molase yang terkandung di dalam campuran briket akan terdorong keluar melalui celah-celah campuran bahan baku. Setelah diamati secara visual, briket batubara yang dihasilkan terlihat lebih kering akibat keluarnya molase dari campuran jika dibandingkan dengan briket yang dicetak pada kuat penekanan dengan gaya yang lebih kecil. Molase yg terintrusi keluar dari campuran briket akan menggenang di bagian bawah cetakan.

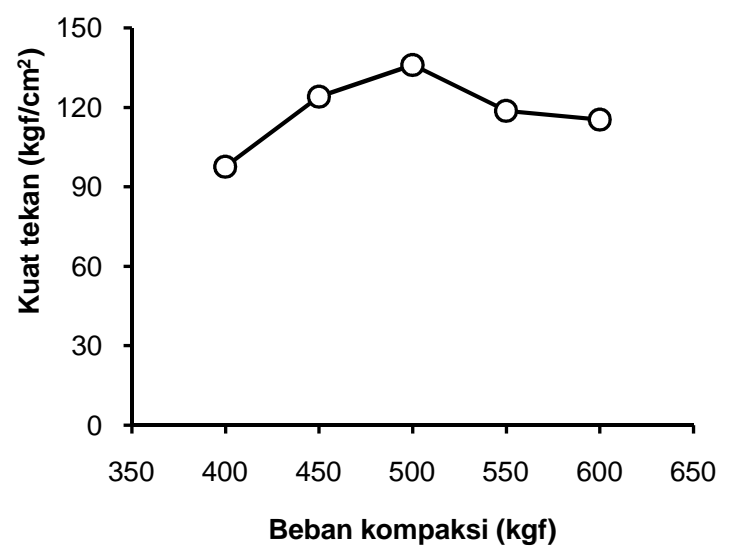

Gambar 4. Pengaruh beban kompaksi terhadap kuat tekan briket

Faktor lain yang mempengaruhi kuat tekan briket adalah komposisi bahan pengikat (binder) yang digunakan. Pengaruh penambahan bahan pengikat molase dapat dilihat pada Gambar 5. Hasil percobaan memperlihatkan bahwa semakin tinggi jumlah bahan pengikat yang digunakan semakin besar kuat tekan briket yang dihasilkan.Pada komposisi bahan pengikat molase sebanyak $15 \%$ dari total campurandihasilkan kuat tekan briket sebesar $85,06 \mathrm{kgf} / \mathrm{cm}^{2}$, penambahan molase hingga $30 \%$ memberikan nilai kuat tekan $132,71 \mathrm{kgf} / \mathrm{cm}^{2}$. Kuat tekan masih cenderung naik pada penambahan bahan pengikat hingga komposisi di atas 30\% dari total campuran.

Nilai kuat tekan yang meningkat seiring banyaknya jumlah molase disebabkan daya rekat binder yang lebih besar. ${ }^{19}$ Namun demikian, penggunaan binder harus dibatasi karena bahan pengikat sendiri pada umumnya memiliki nilai kalori yang lebih rendah dibandingkan sabut kelapa dan abu dasar, sehingga dapat mengakibatkan turunnya nilai kalori bahan baku briket. Penentuan komposisi molase optimum masih harus dievaluasi dari pengaruhnya terhadap nilai kalori briket, yang akan dipaparkan pada pembahasan selanjutnya.

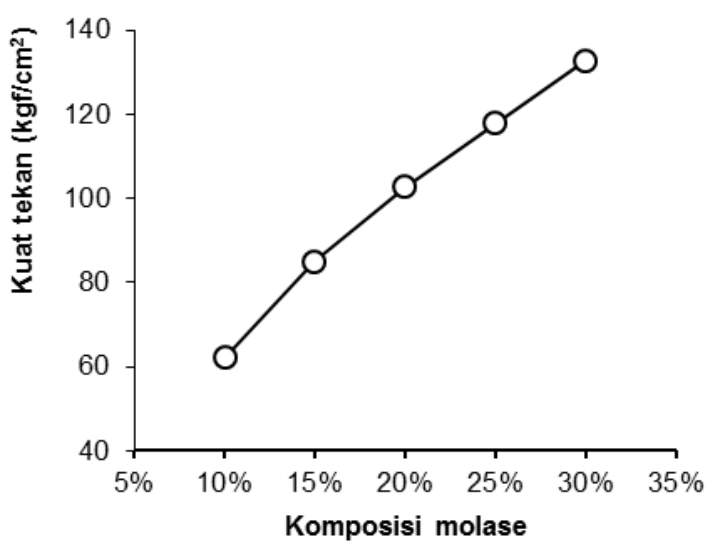

Gambar 5. Pengaruh komposisi molase terhadap kuat tekan briket

Sementara itu, faktor lain yang mempengaruhi kuat tekan briket adalah komposisi bahan baku dan impregnasi yang dilakukan terhadap abu dasar. Pengaruh ini dapat dilihat pada Gambar 6 dan 7. Hasil percobaan pada Gambar 6 menunjukkan bahwa peningkatan komposisi sabut kelapa dalam briket berbanding lurus dengan penurunan kuat tekan briket. Briket dengan campuran molase dan abu dasar saja, memiliki kuat tekan yang lebih baik setelah diberi beban kompaksi. Hal ini disebabkan ukuran partikel halus abu dasar akan membentuk campuran yang kompak dengan molase, kekuatan briket juga semakin meningkat jika dipanaskan dan kadar airnya berkurang. Penggunaan arang sabut kelapa dalam jumlah yang lebih besar akan menurunkan kuat tekan karena struktur arang sabut yang porous dengan densitas yang lebih kecil.

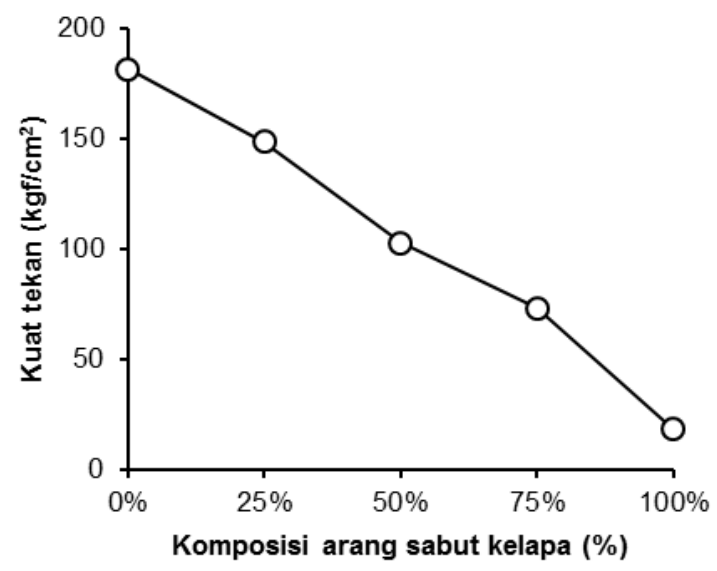

Gambar 6. Pengaruh komposisi arang sabut kelapa terhadap kuat tekan briket 


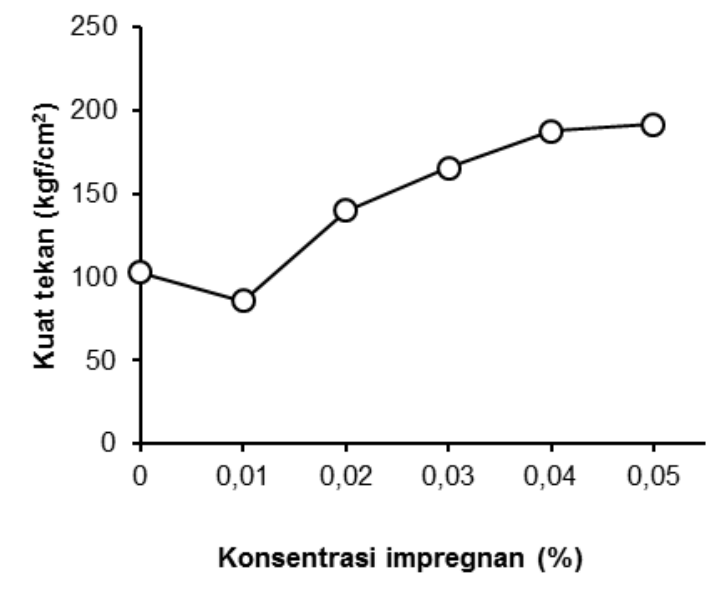

Gambar 7. Pengaruh konsentrasi larutan impregnan pada abu dasar terhadap kuat tekan briket

Pada Gambar 7 dapat dilihat pengaruh impregnasi abu dasar terhadap kuat tekan briket. Kuat tekan briket menurun seiring peningkatan konsentrasi impregnan hingga $0,01 \%$. Proses impregnasi pada konsentrasi rendah akan menurunkan kuat tekan yang disebabkan adanya pelarutan hidrokarbon dan pengotor di permukaan partikel karbon akan membentuk campuran yang lebih porous. Tetapi semakin besar konsentrasi larutan impregnan yang digunakan justru kuat tekan meningkat. Hal ini disebabkan oleh partikel larutan impregnan yang mengisi ruang kosong diantara permukaan sehingga karbon menjadi lebih padat dan tidak rapuh. ${ }^{16}$

\section{Evaluasi terhadap Nilai Kalori Briket}

Nilai kalori produk briket merupakan parameter proses utama yang harus dievaluasi selain dari kuat tekan. Produk briket harus memiliki nilai kalori yang cukup dan mudah untuk dinyalakan. Evaluasi terhadap upaya peningkatan nilai kalori pada bahan baku abu dasar dan sabut kelapa telah dibahas sebelumnya. Pengaruh komposisi molase dalam total campuran briket terhadap nilai kalori dapat dilihat pada Gambar 8 .

Hasil percobaan pada Gambar 8 menunjukkan bahwa peningkatan komposisi molase pada jumlah campuran abu dasar dan sabut kelapa tetap mampu meningkatkan nilai kalori briket. Pada penambahan molase sebanyak $15 \%$ diperoleh kuat tekan briket sebesar $85,06 \mathrm{kgf} / \mathrm{cm}^{2}$ dan nilai kalori sebesar $4433 \mathrm{kkal} / \mathrm{kg}$. Penambahan molase $15 \%$ dianggap sebagai nilai optimum karena sudah memenuhi syarat kuat tekannya serta nilai kalorinya sudah mendekati $4500 \mathrm{kkal} / \mathrm{kg}$,sehingga digunakan sebagai acuan percobaan selanjutnya.

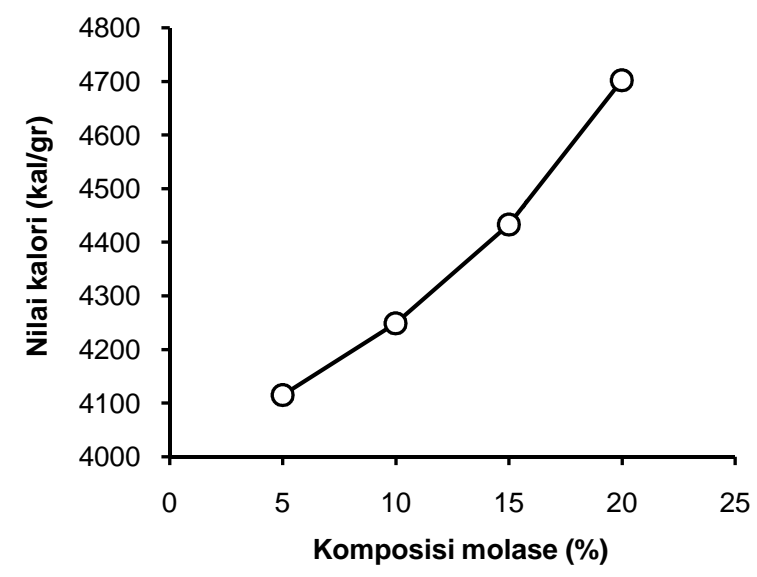

Gambar 8. Pengaruh komposisi molase terhadapnilai kalori briket

Pengaruh komposisi abu dasar dan sabut kelapa pada campuran total dengan penambahan molase sebanyak $15 \%$ terhadap nilai kalori briket ditunjukkan pada Tabel 3. Semakin besar jumlah arang sabut kelapa yang digunakan maka semakin besar nilai kalori karena arang sabut kelapa memiliki nilai kalori yang jauh lebih tinggi dibandingkan abu dasar. Data pada Tabel 3 menunjukkan bahwa penambahan arang sabut kelapa memberikan peningkatan nilai kalori meskipun cenderung menurunkan nilai kuat tekan.

Tabel 3. Hasil Percobaan Variasi KomposisiCampuran Briket

\begin{tabular}{|c|c|c|c|c|c|c|}
\hline \multirow[b]{2}{*}{$\begin{array}{c}\text { Komposisi } \\
\text { AD:SK:ML* }\end{array}$} & \multicolumn{4}{|c|}{ Proksimat } & \multirow[b]{2}{*}{$\begin{array}{c}\text { Nilai } \\
\text { kalori } \\
\text { (kkal/kg) }\end{array}$} & \multirow[b]{2}{*}{$\begin{array}{c}\text { Kuat } \\
\text { tekan } \\
\left(\mathrm{kgf} / \mathrm{cm}^{2}\right)\end{array}$} \\
\hline & $\begin{array}{c}\text { Air } \\
\text { lembab } \\
(\%)\end{array}$ & $\begin{array}{l}\text { Abu } \\
(\%)\end{array}$ & $\begin{array}{c}\text { Zat } \\
\text { terbang } \\
(\%)\end{array}$ & $\begin{array}{c}\text { Karbon } \\
(\%)\end{array}$ & & \\
\hline $42,5: 42,5: 15$ & 3,41 & 25,26 & 35,33 & 36,00 & 4.524 & 69,58 \\
\hline $37,5: 47,5: 15$ & 7,93 & 21,32 & 34,08 & 36,67 & 4.615 & 68,77 \\
\hline $32,5: 52,5: 15$ & 7,97 & 19,80 & 34,65 & 37,58 & 4.704 & 66,98 \\
\hline $27,5: 57,5: 15$ & 7,95 & 18,78 & 36,40 & 36,87 & 4.915 & 65,86 \\
\hline $22,5: 62,5: 15$ & 7,75 & 16,09 & 38,08 & 38,08 & 5.185 & 63,99 \\
\hline
\end{tabular}

*AD : abu dasar, SK : sabut kelapa, ML : molase 
Peningkatan komposisi arang sabut kelapa pada variasi percobaan dari $42,5 \%$ hingga $62,5 \%$ secara linear mampu meningkatkan nilai kalori briket. Komposisi arang sabut kelapa 62,5\% memberikan kuat tekan briket yang masih memenuhi syarat $\left(63,99 \mathrm{kgf} / \mathrm{cm}^{2}\right)$ sekaligus menghasilkan nilai kalori yang sangat baik (5.185 $\mathrm{kkal} / \mathrm{kg}$ ). Namun demikian, penambahan komposisi arang sabut kelapa dalam briket relatif kurang ekonomis pada skala produksi meskipun menghasilkan nilai kalori yang baik. Pengurangan komposisi arang sabut kelapa memberikan pengaruh positif pada peningkatan kuat tekan briket, sebagaimana terlihat pada Tabel 3. Di sisi lain, penggunaan komposisi abu dasar yang lebih tinggi sangat menguntungkan ditinjau dari aspek lingkungan, mengingat keberadaannya sebagai limbah industri tekstil.

Berdasarkan evaluasi pada variasi komposisi dan pertimbangan yang dijelaskan di atas, maka komposisi optimum pembuatan briket pada skala aplikasi adalah dengan perbandingan abu dasar : sabut kelapa : molase $=42,5: 42,5: 15$, dengan nilai kalori $4.524 \mathrm{kkal} / \mathrm{kg}$ dan kekuatan tekan sebesar $69,58 \mathrm{kgf} / \mathrm{cm}^{2}$. Komposisi ini merupakan optimum dalam memenuhi tujuan penelitian ini yaitu diperolehnya briket yang memenuhi persyaratan teknis nilai kalori dan kuat tekan untuk digunakan sebagai sebagai bahan bakar padat. Briket yang dibuat dengan perbandingan tersebut di atas ditunjukkan pada Gambar 9.

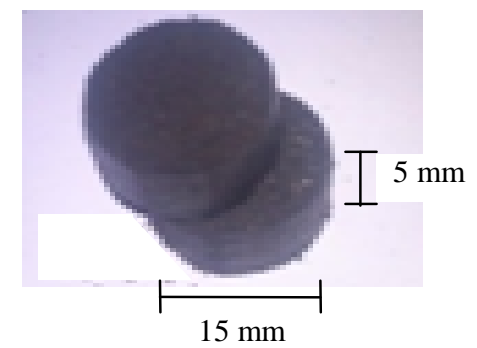

Gambar 9. Briket abu dasar/sabut kelapa/ molase dengan komposisi 42,5 : 42,5: 15.

\section{KESIMPULAN}

Pada penelitian ini dapat diambil kesimpulan sebagai berikut:

- Pengarangan terhadap sabut kelapa mampu meningkatkan nilai kalori seiring peningkatan temperatur proses. Nilai kalori arang sabut kelapa diperoleh sebesar $7122 \mathrm{kkal} / \mathrm{kg}$ pada temperatur pengarangan $300^{\circ} \mathrm{C}$.

- Proses impregnasi selama 24 jam memberikan peningkatan nilai kalori yang tidak terlalu signifikan. Peningkatan nilai kalori tertinggi diperoleh melalui impregnasi pada konsentrasi $\mathrm{NaCl} 0,02 \%$ dengan peningkatan nilai kalori dari $2.177 \mathrm{kkal} / \mathrm{kg}$ menjadi $2.764 \mathrm{kkal} / \mathrm{kg}$.
Komposisi bahan pengikat (binder) sebanyak $15 \%$ dari campuran memberikan nilai kuat tekan sebesar $85,06 \mathrm{kgf} / \mathrm{cm}^{2}$. Semakin banyak jumlah bahan pengikat yang ditambahkan maka kuat tekan briket akan semakin baik.

Beban kompaksi optimum sebesar 500 kgf memberikan nilai kuat tekan $135,99 \mathrm{kgf} / \mathrm{cm}^{2}$. Pemberian beban kompaksi di atas $500 \mathrm{kgf}$ dapat menyebabkan penurunan kuat tekan briket.

Pada kondisi percobaan optimum (temperatur pengarangan $300^{\circ} \mathrm{C}$, komposisi binder $15 \%$, dan beban kompaksi $500 \mathrm{kgf}$ ), komposisi optimum briket sebagai perbandingan persentase berat abu dasar, arang sabut kelapa dan molase (AD:SK:ML) adalah 42,5 : 42,5 : 15yang menghasilkan nilai kalori $4.524 \mathrm{kkal} / \mathrm{kg}$ dan mencapai kuat tekan $69,58 \mathrm{kgf} / \mathrm{cm}^{2}$. Hasil ini menunjukkan briket yang dibuat memenuhi persyaratan teknis nilai kalori dan kuat tekan untuk digunakan sebagai sebagai bahan bakar padat.

\section{PUSTAKA}

${ }^{1}$ Suripto, Pujiono \& Mochtar, 2009. Pemanfaatan Limbah Abu Terbang dan Debu Marmer untuk Bahan Baku Pembuatan Ubin Keramik Berpori, Balai Besar Keramik, Prosiding Seminar Nasional Keramik VIII, Balai Besar Keramik hal 20-30.

${ }^{2}$ Prijatama,H. \& Sumarnadi, E.T., 1996. Pemanfaatan Limbah Abu Batubara PLTU, Puslitbang Geoteknologi LIPI, Bandung, Prosiding hasil Litbang Ilmu Pengetahuan Teknik, Bandung.

${ }^{3}$ Nurhakim, M.Z., 2014. Studi Pengaruh Penambahan Katalis $\mathrm{Fe}_{2} \mathrm{O}_{3}$ Hasil Presipitasi Terhadap Pembakaran Batubara. Tugas Akhir. Institut Teknologi Bandung.

${ }^{4}$ Rismayani, S., 2008. Pembuatan Bio-Briket Dari Limbah Sabut Kelapa dan Bottom Ash, Laporan Penelitian, Balai Besar Tekstil.

${ }^{5}$ Davies, M.C. 1985. Understanding Briquettes. Virginia : Volunteers of Technical Assistants.

${ }^{6}$ Sun, B., Yu, J., Tahmasebi, A., Han, Y., 2014. An experimental study on binderless briquetting of Chinese lignite: Effects of briquetting conditions, Fuel Processing Technology 124, 243-248.

${ }^{7}$ Benk, A., 2010. Utilisation of the binders prepared from coal tar pitch and phenolic resins for the production metallurgical quality briquettes from coke breeze and the study of their high temperature carbonization behaviour, Fuel Processing Technology91, 1152-1161. 
${ }^{8}$ Rismayani, S., Winiati, W., Indarto, Ariwahjoedi, B., 2007. Pemanfaatan Limbah Bottom Ash sebagai Adsorben Limbah Zat Warna Industri Tekstil, Jurnal Riset Industri, Vol.1, No.3.

${ }^{9}$ Anonim, 2010. Reuse Limbah Pembakaran Batubara untuk Briket dan Pupuk Organik, LPTI Pelataran Mataram, Yogyakarta.

${ }^{10}$ Tirono, M. \& Sabit, A., 2011. Efek Suhu pada Proses Pengarangan Terhadap Nilai Kalor Arang Tempurung Kelapa. Jurnal NeutrinoVol.3 No.2.

${ }^{11}$ Shi, Y., Hairui, Y., Jiansheng, Z., Junfu, L. Guangxi, Y., 2004. Co-Combustion of Compressed Biomass and Coal in a CFB Boiler, Thermal Engineering, Tsinghua University Beijing, China.

${ }^{12}$ Vassilev, S.V., Vassileva, C.G. Vassilev, V.S., 2015. Advantages and disadvantages of composition and properties of biomass in comparison with coal: An overview, Fuel, http://dx.doi.org/ 10.1016/ j.fuel.2015.05.050

${ }^{13}$ Chiiti, Y. \& Kemiha M., 2013. Thermal Conversion of Biomass, Pyroliysis and Gasification : A review. The International Journal of Engineering and Science 2 (3), $75-85$
${ }^{14}$ Hu, J., Lei, T., Wang, Z., Yan, X., Shi, X., Li, Z., et al., 2014. Economic, environmental and social assessment of briquette fuel from agricultural residues in China : A study on flat die briquetting using corn stalk, Energy 64, 557-566.

${ }^{15}$ Yaman, S., Sahan, M., Haykiriacma, H., Sesen, K., Kucukbayrak, S., 2000. Production of fuel briquettes from olive refuse and paper mill waste, Fuel Processing Technology68, 23-31.

${ }^{16}$ Marsh, H. \& Reinoso, F.R. 2006. Activated Carbon. Elsevier Science \& Technology Books

${ }^{17}$ Križan, P., Šooš, L., Vukelić, D., 2009. Study of ImpactTechnological Parameters on The Briquetting Process. Fakta Universitatis.

${ }^{18}$ Liu, Y., Wang, X., Xiong, Y., Tan, H., Niu, Y., 2014. Study of briquetted biomass co-firing mode in power plants, Applied Thermal Engineering 63, 266-271.

${ }^{19}$ Davies, R.M., 2013. Mechanical Handling Characteristic of Briquettes Produced from Water Hyacinth and Plantain Peel as Binder. Science Domain International. 